\title{
Resume Matakuliah Hukum Tatanegara
}

Adinda Putri Septiani

10200120197

\section{HTN E}

\section{Pengertian Hukum Tata Negara}

Hukum Tata Negara adalah hukum yang mengatur tentang pengelolaan, penataan dan pengaturan organisasi kekuasaan disuatu wilayah tertentu yang berkenaan dengan hubungan antara pemerintah dengan warga negaranya.

\section{Pengertian Hukum Tata Negara menurut para ahli:}

1. Van Vallenhoven

Hukum Tata Negara mengatur semua masyarakat hokum atasan dan masyarakat hokum bawahan menurut tingkatannya dan dari masing-masing itu menentukan wilayah lingkungan rakyatnya, dan akhirnya menentukan badan-badan dan fungsinya masing-masing yang berkuasa dalam lingkungan masyarakat hokum itu serta menentukan susunan dan wewenang badanbadan tersebut.

\section{Kusumadi Pudjosewojo}

Hukum Tata Negara adalah hokum yang mengatur bentuk negara (kesatuanataufederal), dan bentuk pemerintahan (kerajaan atau republik), yang menunjukan masyarakat Hukum yang atasan maupun yang bawahan, besertating katan-tingkatannya (hierarki), yang selanjutnya mengesahkan wilayah dan lingkungan rakyat dari masyarakat-masyarakat hukum itu dan akhirnya menunjukan alat-alat perlengkapan (yang memegang kekuasaan penguasa) dari masyarakat hokum itu, beserta susunan (terdiri dari seorang atau sejumlah orang), wewenang, tingkatan imbang dari dan antara alat perlengkapan itu.

\section{J.R.Stellinga}

Hukum Tata Negara adalah hokum yang mengatur wewenang dan kewajiban-kewajiban alat-alat perlengkapan negara, mengaturhak, dan kewajiban warga negara.

\section{Ruang lingkup HTN}

Ruang lingkup kajian Hukum Tata Negara adalah mengenai organisasi Negara yang mencakup mengenai lembaga-lembaga negara, hubungan satu dengan yang lain, dan kekuasaannya. Selain itu, juga mencakup mengenai warga negara termasuk Hak Asasi Manusia (HAM), dan wilayah negara.

Secara umum dapat dikatakan bahwa terdapat 4 (empat) hal pokok yang menjadi ruang lingkup Hukum Tata Negara, yaitu:

1. Struktur umum organisasi negara;

2. Badan-badan ketatanegaraan; 
3. Pengaturan kehidupan politik rakyat;

4. Sejarah perkembangan ketatanegaraan suatu negara.

\section{Sumber Hukum Tata Negara}

\section{Sumber Hukum Tata Negara dalam arti materil}

Seperti telah dikemukakan bahwa sumber dalam arti material ialah berkenaan dengan menganalisis dari sudut muatan atau materi hukumnya.

\section{Sumber Hukum Tata Negara dalam artiformal}

Sumber hukum dalam arti formal bagaimana bentuk daripada hokum tersebut. Formal (kenbron) menunjukkan kepada jenis-jenis hukum.

Berikut ini akan di bahas beberapa jenis sumber hokum formal dari Hukum Tata Negara, yaitu sebagai berikut:

1. Undang Dasar 1945, merupakan sumber hukum bagi Hukum Tata Negara di Indonesia

2. Ketetapan Majelis Permusyawaratan Rakyat

3. (UU) dan Peraturan Pemerintah Pengganti Undang-undang (PERPU)

4. Peraturan pemerintah

5. Keputusan Presiden

6. Peraturan daerah provinsi

7. Peraturan daerah kabupaten/kota

\section{Asas-asas Hukum Tata Negara}

1. Asas Pancasila

Asas Pancasila merupakan prinsip dasar dan utama dalam kehidupan negara indonesia.

Pancasila dijadikan pedoman hidup dan memiliki 5 butir nilai, yang mana aturan manapun termasuk undang-undang harus mengikutinya.

\section{Fungsi Asas Pancasila}

1. Pancasila dijadikan sebagai jiwa dari bangsa indonesia, sehingga setiap visi dan misi selalu menjunjung asas pancasila.

2. Pancasila merupakan kepribadian bangsa indonesia, sebagai identitas nasional, dimana tutur kata dan perilaku rakyat indonesia merupakan cerminan dari asas pancasila.

3. Pancasila dijadikan pandangan bangsa indonesia dalam hidup bernegara. 
4. Pancasila sebagai dasar Negara dimana semua system pemerintahan berlangsung dengan berlandaskan asas pancasila.

5. Pancasila dijadikan sumber dari semua sumber hukum yang ada dilndonesia, sehingga dalam pembuatan aturan harus mengikuti asas pancasila.

6. Pancasila sebagai perjanjian luhur ketika didirikannya negara indonesia.

7. Pancasila dijadikan sebaga icita-cita bangsa Indonesia menuju negara yang sejahtera, adil dan makmur.

\section{Asas Negara Hukum}

Asas negara hukum menyatakan bahwa negara indonesia merupakan Negara yang berlandaskan hukum.

Pernyataan ini juga disampaikan di Undang-undang Dasar 1945.

Negara hokum bermakna bahwa suatu Negara tersebut memihak akan keadilan dan kesejahteraan rakyat, bukan atas dasar kekuasaan pemerintah semata.

\section{Fungsi Asas Negara Hukum}

1. Dengan adanya asas negara hukum, suatu negara akan lebih melindungi hak asasi manusia.

2. Pemerintahan akan berdasarkan pada aturan yang berlaku.

3. Adanya pembagian dan pemisahan kekuasaan negara demi menjamin perlindungan hak asasi manusia dan mencegah pelanggaran HAM.

4. Rakyat akan tunduk pada aturan hukum sehingga meminimalisir pelanggaran social dan norma.

\section{Asas Negara Kesatuan}

Asas Negara kesatuan merupakan prinsip dasar bahwa suatu negara tersebut merupakan Negara berdaulat sebagai satu kesatuan.

Negara kesatuan menjadikan suatu pemerintahan pusat adalah puncak dari segala pemerintahan dan kekuasaan yang ada dipilih oleh pemerintah pusat.

\section{Fungsi Asas Negara Kesatuan}

1. Dengan adanya asas negara kesatuan, segala kekuasaan tergabung dalam pusat pemerintahan.

2. Apabila adanya serangan, negara akan bersatu melawan tanpa memecahbelah masing-masing.

3. Ada bagian-bagian tersendiri yang mengatur dalam menegakkan keadilan.

4. Menjadikan tujuan Negara dalam focus yakni mencerdaskan kehidupan dan melindungi segenap bangsa, memajukan kesejahteraan umum dan ikut melaksanakan ketertiban dunia.

\section{Asas Kedaulatan Rakyat}

Kedaulatan memiliki arti lain sebagai kekuasaan pemerintahan. Asas kedaulatan rakyat berarti prinsip negara yang menunjukkan bahwa kekuasaan pemerintah berada ditangan rakyat, untuk 
rakyat, oleh rakyat. Asas ini tertuang dalam UUD 1945 yang menjelaskan bahwa pemikiran dan ide berasal dari rakyat, atas persetujuan rakyat dan dilakukan oleh Majelis Permusyawaratan Rakyat.

\section{Fungsi Asas Kedaulatan Rakyat}

1. Dengan diterapkannya asas kedaulatan rakyat, maka kekuasaan sepenuhnya berada ditangan rakyat.

2. Rakyat paham atas kondisi mereka sehingga bias tau bagaimana cara tepat untuk mensejahterakan kehidupan.

3. Rakyat dapat mengatur pemerintah untuk menuju kesejahteraan tanpa harus terinjak kekuasaan.

\section{Asas Pembagian Kekuasaan}

Asas pembagian kekuasaan menunjukkan bahwa Negara Indonesia memiliki prinsip membagi kekuasaan disetiap daerah.

Hal ini dilakukan agar tidak terjadinya kekuasaan semena-mena yang dilakukan oleh satu pemimpin atau kelompok. Oleh karenanya dibagilah kekuasaan tersebut untuk mencegah pemimpin atau kelompok mendapatkan kuasa yang terlalu banyak. Meski begitu, masing-masing kekuasaan tetap saling bekerjasama satu sama lain.

\section{Fungsi Asas Pembagian Kekuasaan}

1. Dengan diterapkannya asas pembagian kekuasaan, masing-masing pemimpin atau kelompok lebih terfokus pada pekerjaannya.

2. Kekuasaan stabil dan tidak timpang sebelah akibat pemimpin atau kelompok memiliki banyak kuasa dan mencegah adanya penyalahgunaan kuasa.

\section{Sila Ke-1 "Ketuhanan Yang Maha Esa"}

1. Bangsa indonesia menyatakan kepercayaannya dan ketakwaannya terhadap Tuhan Yang Maha Esa.

2. Manusia Indonesia percaya dan takwa terhadap Tuhan Yang Maha Esa, sesuai dengan agama dan kepercayaannya masing-masing menurut dasar kemanusiaan yang adil dan beradab.

3. Mengembangkan sikap hormat menghormati dan bekerjasama antara pemeluk agama dengan penganut kepercayaan yang berbeda-beda terhadap Tuhan Yang Maha Esa.

Sila Ke-2 "Kemanusiaan yang Adil dan Beradab"

1. Mengakui dan memperlakukan manusia sesuai dengan harkat dan martabatnya sebagai makhluk Tuhan Yang Maha Esa.

2. Mengakui persamaan derajat, persamaan hak, dan kewajiban asasi setiap manusia, tanpa membeda-bedakan suku, keturunan, agama, kepercayaan, jenis kelamin, kedudukan sosial, warna kulit dan sebagainya.

3. Mengembangkan sikap saling mencintai sesame manusia. 
1. Mampu menempatkan persatuan, kesatuan, serta kepentingan dan keselamatan bangsa dan negara sebagai kepentingan bersama diatas kepentingan pribadi dan golongan.

2. Sanggup dan rela berkorban untuk kepentingan negara dan bangsa apabila diperlukan.

3. Mengembangkan rasa cinta kepada tanah air dan bangsa.

Sila Ke-4 "Kerakyatan yang Dipimpinoleh Hikmat Kebijaksanaan dalam Permusyawaratan/Perwakilan"

1. Sebagai warga Negara dan warga masyarakat, setiap manusia indonesia mempunyai kedudukan, hak dan kewajiban yang sama.

2. Tidak boleh memaksakan kehendak kepada orang lain.

3. Mengutamakan musyawarah dalam mengambil keputusan untuk kepentingan bersama.

Sila Ke-5 "KeadilanSosialBagiSeluruhRakyatIndonesia"

1. Mengembangkan perbuatan yang luhur, yang mencerminkan sikap dan suasana kekeluargaan dan kegotong-royongan.

2. Mengembangkan sikap adil terhadap sesama.

3. Menjaga keseimbangan antara hak dan kewajiban.

\section{Asas-asas Hukum Umum}

Peraturan perundang-undangan tidak berlaku surut (non retroaktif).

Peraturan perundang-undangan yang dibuat hanya berlaku pada peristiwa peristiwa hokum yang terjadi setelah peraturan perundang undangan itu lahir. Namun demikian, mengabaikan asas ini

dimungkinkan terjadi dalam rangka untuk memenuhi keadilan masyarakat

Asas kepatuhan pada hirarkhi (lex superior derogat legi inferior). Peraturan perundangundangan yang ada dijenjang yang lebih rendah tidak boleh bertentangan dengan peraturan perundang-undangan yang berada pada jenjang lebih tinggi dan seterusnya sesuai dengan hierarki norma dan peraturan perundang-undangan.

Peraturan perundang-undangan yang bersifat khusus menyampingkan peraturan perundangundangan yang bersifat umum (lex specialis derogate lex generalis).

Peraturan perundang-undangan yang berlaku belakangan membatalkan peraturan perundangundangan yang berlaku terdahulu (lex posterior derogate legi perior) dalam setiap peraturan perundang-undangan biasanya terdapat klausul yang menegaskan keberlakuan peraturan

Perundang-undangan tersebut dan menyatakan peraturan perundang-undangan sejenis yang sebelumnya digunakan, kecuali terhadap pengaturan yang tidak bertentangan. 


\section{Sejarah Ketatanegaraan Indonesia}

Sejarah ketatanegaraan di Indonesia dapat dibagi menjadi beberapa periode, yaitu periode prakemerdekaan dan periode pasca kemerdekaan dan reformasi. Sistem ketatanegaraan dan pemerintahan yang dilaksanakan oleh Pemerintah Kerajaan Belanda adalah menggunakan asas dekonsentrasi dan pada masa pendudukan Jepang paham militeristik menjadi model bagi pengaturan system ketatanegaraan dilndonesia.

Pada tanggal 18 Agustus 1950, UUDS 1950 dinyatakan berlaku, UUDS 1950 ini sangat berbeda dengan UUDS 1945 hasil proklamasi terutama system pemerintahan yang parlementer, kepada pemerintahan dipimpin oleh perdana menteri. Dengan dekrit presiden 5 Juli 1959 berlakulah kembali UUDS 1945. Dasar hokum dekrit ini ialah Saatsnoodrecht. Dibawah UUD 1945 ini untuk pertamakali dilaksanakan pemilihan umum.

\section{Hubungan negara dengan konstitusi}

Letak hubungan dasar Negara dengan konstitusi adalah dari aturan dasar tersebut akan dibentuk keseluruhan system ketatanegaraan yang berupa kumpulan peraturan yang mengatur pemerintahan suatu negara, salah satunya adalah konstitusi atau UUD.

\section{Secara Yuridis}

Hubungan dasar negara dengan konstitusi bahwa konstitusi mengandung pokok-pokok pikiran dasar negara yang berwujud pasal-pasal.

\section{Secara Filosofis}

Konstitusi didasarkan pada filosofi bangsa tersebut yang berakar pada budaya bangsa.

\section{Secara Sosiologis}

Konstitusi bisa memuat nilai-nilai yang berkembang dimasyarakat yang bersumber dari dasar negara dalam penyelenggaraan pemerintahan.

\section{Hubungan Dasar Negara dan Konstitusi di Indonesia}

Bisa dilihat dari hubungan antara sila-sila pancasila yang termuat pada Pembukaan UUD 1945 dengan pasal-pasal yang termuat dalam batang tubuh UUD 1945.

Pasal-pasal UUD merupakan penjabaran dari pokok-pokok pikiran yang ada dalam Pembukaan UUD 1945 .

Hubungan dasar negara dengan pembukaan UUD 1945 dapat digambarkan sebagai berikut

Falsafah dasar Negara Pancasila yang abstrak tercermin dalam Pembukaan UUD 1945 yang merupakan uraian detail dari Proklamasi 17 Agustus 1945.

Pancasila yang dirumuskan dalam Pembukaan UUD 1945 adalah suatu kebulatan yang utuh dan tersusun secara teratur dan bertingkat. Sila yang satu menjiwai sekaligus meliputi sila yang lain secara bertingkat. 
Jiwa Pancasila yang abstrak, setelah terlahir menjadi Proklamasi Kemerdekaan RI 17 Agustus 1945 tercermin dalam pokok-pokok pikiran yang termuat dalam Pembukaan UUD 1945.

Kesatuan tafsir sila-sila Pancasila mesti bersumber dan berdasarkan Pembukaan dan pasal-pasal UUD 1945.

\section{Organisasi dan fungsi kekuasaan negara}

Adalah sebuah lembaga pemerintahan negara yang berwenang untuk mengatur, menata dan mengelola segala hal yang menyangkut tentang perihal negara.

\section{Menurut Charles E. Merriam}

Merriam mengemukakan tentang tujuan-tujuan negara (Samindo, 1986: 220-222)

\section{a. Keamanan Eksternal}

Dengan keamanan eksternal (external security) maksudnya seluruh tugas-tugas perlindungan negara terhadap serangan dari luar terhadap kelompok sendiri.

b. Ketertiban Internal

Pemeliharaan ketertiban internal (maintenance of intern order) adalah tujuan negara yang kedua. Dengan tertib, dimaksudkan sistem dalam mana dapat diaadakan perkiraan-perkiraan yang layak tentang apa yang akan dilakukan dalam bidang sosial dan siapa yang akan melakukannya.

c. Keadilan

Keadilan (justice) terwujud dalam sistem dimana terdapat saling pengertian dan prosedurprosedur yang memberikan kepada setiap orang apa yang telah setujui dan telah dianggap patut.

\section{d. Kesejahtraan Umum}

Menurut Merriam, pengertian kesejahteraan ini meliputi usaha-usaha, seperti : penembahan tenaga produksi yang dapat memperbesar pendapatan nasional, memlihara tingkat kehidupan minimal bagi semua individu sesuai dengan tingkat produksi, menyelenggarakan usaha-usaha dalam bidang teknologi, dalam bidang pendidikan, dan lain-lain.

\section{e. Kebebasan}

Kebebasan (freedom) sebagai tujuan negara yang kelima dan terakhir, merupakan tujuan negara yang esensial. Yang dimaksud dengan kebebasan ialah kesempatan mengembangkan dengan bebas hasrat-hasrat individu akan ekspresi kepribadiannya yang harus disesuaikan dengan gagasan kemakmuran umum. 